\title{
MYTHS OF GESTATION AND PARTURITION
}

\section{BY WASHINGTON MATTHEWS}

Perhaps when the reader has finished this paper he will place me in the category with the fabled shoemaker who, when the city was in danger and its wise men were considering how best to fortify it, declared, "There is nothing like leather." In something connected with my own special craft, I seek the solution of a difficult problem.

I shall discuss the origin of a myth which is of wide distribution on the American continent and the islands of the Pacific ocean, and has its traces in the eastern world. In this myth, or series of allied myths, the human race is represented as having originated within the earth and as having emerged to its surface through a hole in the ground. The ascent from the lower world is represented as accomplished by means of a tree, vine, or reed, and a deluge is usually associated with the emergence.

Attempts have been made to account for the origin of this myth. The most scholarly of these appears in an essay by the late Horatio Hale entitled "Above and Below." He believed the myth to have arisen from a "disease of language," and to be founded on migration; that in America it refers to a tribe of Indians moving up a river or against the current and that in the South Sea islands it refers to a migration in the direction of the prevailing winds. Hale presents many excellent reasons in support of this theory; but he does not consider the significant fact that there are no myths of descent. Supernatural beings may descend from the sky, but not men; mortals may visit the sky and return from it, but the races of mankind had their origin in the earth and have emerged thence. A migration down a river is more AM. ANTH, N. S., 4-47 
easy than one in the opposite direction, and, no doubt, many such migrations have occurred. Why, then, have we no myths of descent? In the Pacific islands a migration with the wind is more easy than one against it, and here the theory of migration might easily be held to account for this myth; but not so on the continent of America.

Instead of reserving my conclusion as to the origin of this myth to the end of my essay, I think it will make my argument shorter and clearer if I state it here. The "Story of the Emergence," as I have already named it in a previous work, I believe to be a myth of gestation and of birth. For many years the problem of this myth has shared my thoughts. Long ago I arrived at the solution I now offer, and years of consideration have led me to feel confidence in it rather than doubt.

Among all our Indian tribes, so far as studied, the earth is at least personified as a woman and a mother, and perhaps the ideas of some Indians, in this respect, are more than mere personification. The idea of the maternity of the earth may have been derived from its fruitfulness and the idea of the masculinity of the sun or the sky, from the obvious effect of sunlight or rain upon that fruitfulness; but with some Indian tribes the conception seems to be more precise and material than this-more gross, we might say. "You ask me to plow the ground," said Smohalla, the Umatilla prophet. "Shall I take a knife and tear my mother's bosom? You ask me to dig for stone. Shall I dig under her skin for her bones? You ask me to cut grass and make hay and sell it and be rich like white men. But how dare I cut off my mother's hair?"'

I desire, in this paper, to be brief. I write not so much in the hope of settling the question I have raised as in the hope of exciting discussion and directing the investigations of younger students. From the myths of various tribes I might bring forward a

1 “The Ghost Dance Religion," by James Mooney. Fourteenth Annual Report of the Buriau of Ethnology, p. 708 . 
wealth of illustration; indeed, it would not be difficult to write a large volume on the subject; but I shall confine myself to a few quotations which are necessary as a basis for my argument.

In the Navaho language, the earth is called Naëstsán, which means, literally, "Woman Horizontal," or "Woman Lying Down." It is likened to a woman lying supine. The sky, called Yád̆ly̆l, or "Upper Darkness," is said to be her husband. In some of the Navaho myths the creation of different animals and divine beings is attributed to a visible contact between the earth and the sky, as when clouds hang low on the mountains or cyclones descend. They believe in four subterranean worlds, which may be likened to wombs of the earth, as the people of Zunit call them; but if thus they speak of more than one lower world it is that they may employ their sacred number four, as they usually do, to the weariness of their civilized hearers.

The place whence men emerged to the surface of this world is, with many tribes, a lake, and a flood of water drives them out or accompanies the exit. These features in the tale must be suggestive to the tocologist.

A tree with some tribes, a vine with the Mandans, a giant reed with the Navahoes, affords means of escape from the lower world to this, and this element in the story is not without its tocological significance. A singular feature of this part of the tale occurs in the myth of the Mandans of North Dakota. In this, as told to me some thirty years ago, they said that their ancestors escaped from the lower world by means of a vine which was not like the vines we usually see on this earth,- - that it twisted from left to right as it ascended. Such is the way in which the funis coils.

In the creation myths of $\mathrm{Zuni},{ }^{1}$ as related by Mr Cushing, the story of the emergence is well elaborated and its physiological character seems easy to trace. The fecundation of the Earth

1" Outlines of Zuñi Creation Myths," by Frank Hamilton Cushing. Thirteenth Annual Report of the Bureau of Ethnology, pp. 379-383. 
Mother by the Sky Father is plainly told. The relations of the four wombs of the Earth to parts of the human anatomy are rudely indicated, and a ladder is described, made of grasses and vines, by which the people are said to have ascended. An allusion is made to a body of water at the place of emergence, but not with the exactness and elaboration which the myths of other tribes give us.

In Cushing's Zuñi Folk Tales there is yet another myth of this character, "The Twins of War," which apparently has no connection with the regular creation legend or origin legend of the Zuni Indians. In this it is told that the twins descended, through a lake, to the under world and found there an unstable and vaporous people who lived not on solid food, but on the vapors and odors of food. They had, in short, "no visible means of support," and were horrified when they saw the Twins of War eating solid substances which the people of the under world had been accustomed to throw away. After various adventures a number of these people were brought to the upper world. Near the end of the story we find the following significant paragraph :

"And for this reason, behold! a new-born child may eat only of wind-stuff, until his cord of viewless sustenance has been severed, and then only by sucking milk or soft food first and with much distress."

There are some interesting points of resemblance between ${ }^{1}$ the American mythic Tree of Emergence, as we may call it, and Ygdrasil or the "Tree of Existence" of Norse mythology, as there are between the former and the physiological tree of existence; but I shall present only a few of these. I quote the following from Prof. Rasmus B. Anderson's Norse Mythology": "Odin himself, in his famous Rune-song in the Elder Edda, says :

1 Zuñ Folk Tales, Recorded and Translated by Frank Hamilton Cushing, New York and London, Igor, p. 409.

${ }^{2}$ Chicago, 1879, p. 254. 


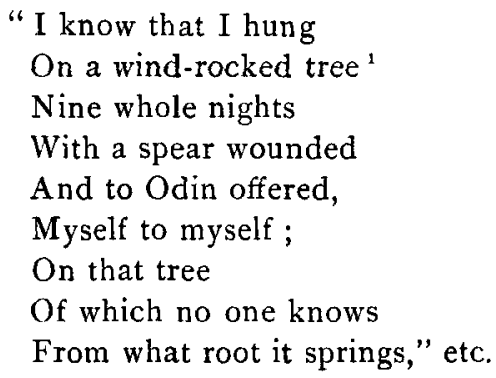

Elsewhere in the same work, Professor Anderson thus comments on this passage: "Odin hung nine days on the tree (Ygdrasil) and sacrificed himself to himself and wounded himself with his own spear. This has been interpreted to mean the nine months in which the child is developed in its mother's womb. Turn back and read the first strophes carefully and it will be found that there is some sense in this interpretation." 3 But Professor Anderson follows these remarks by giving some ingenious and exalted reasons for doubting the interpretation.

Supposing that something had been published on this subject, I recently took the liberty of writing to Professor Anderson to inquire in what work I might find the discussion. Under date of Sept. Igth, 1902, I received the following reply: "I am sorry I am not able to refer you to any discussion [of the relation] of Ygdrasil to parturition. The idea occurred to me when I prepared my mythology for publication. I have talked with Scandinavian mythologists on the subject and they say the nine days is suggestive." It seems, then, that this conjecture concerning Ygdrasil is Professor Anderson's own. But there are other things suggestive besides the nine days and the wounding of Odin with his own spear.

The Scandinavian Tree of Existence, it is said, sprung from three roots. This feature of the myth might be easily explained by saying that three was a sacred number with the northern myth-makers, and we all know how prone myth-makers are to 
introduce sacred numbers into their tales. Yet it must occur to the anatomist that the funis consists of three obvious elementstwo arteries and a vein-and that, before circulation ceases, it apparently arises from three roots.

The old Norwegian story-tellers and bards so clothed their great Tree of Life with poetic imagery that it

"Flashed like the plane tree the Persian adorned with mantles and jewels,"

and it has become difficult for us to distinguish its original form. But I believe a careful study of the Gothic myths will yet reveal that the wonderful Ygdrasil, "a most sublime and finished myth," as Professor Anderson truly calls it, was, in the beginning, nothing more poetic than that which every midwife beholds when she performs her special functions. 



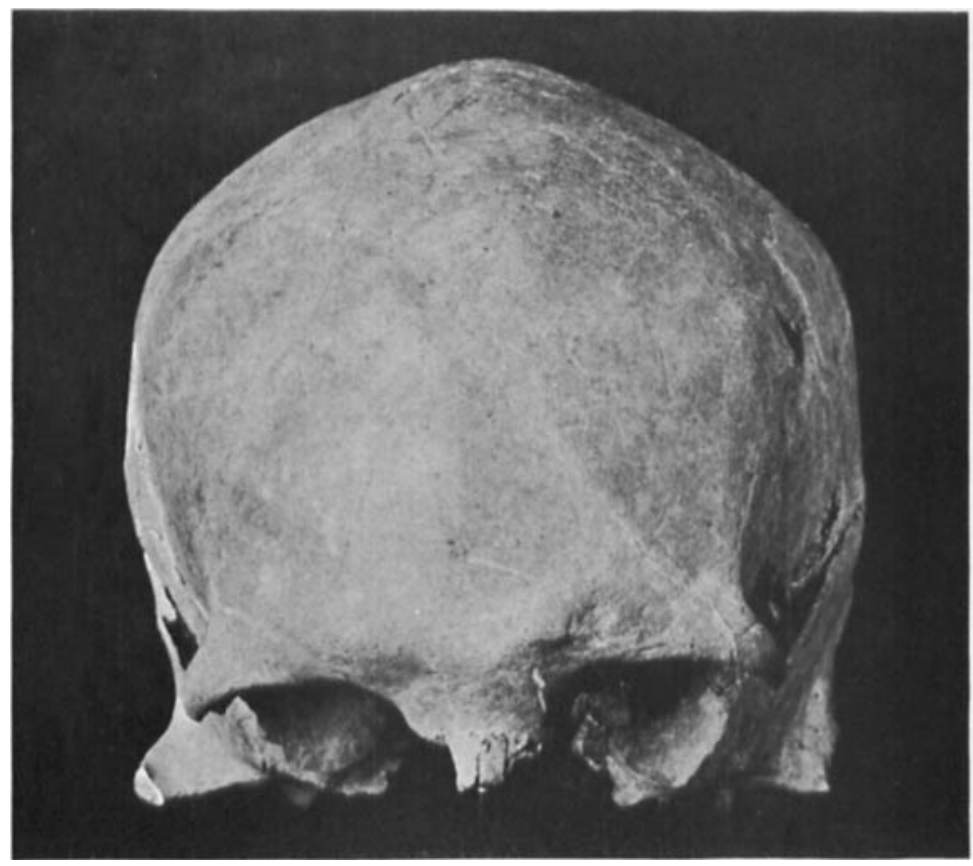

$a$

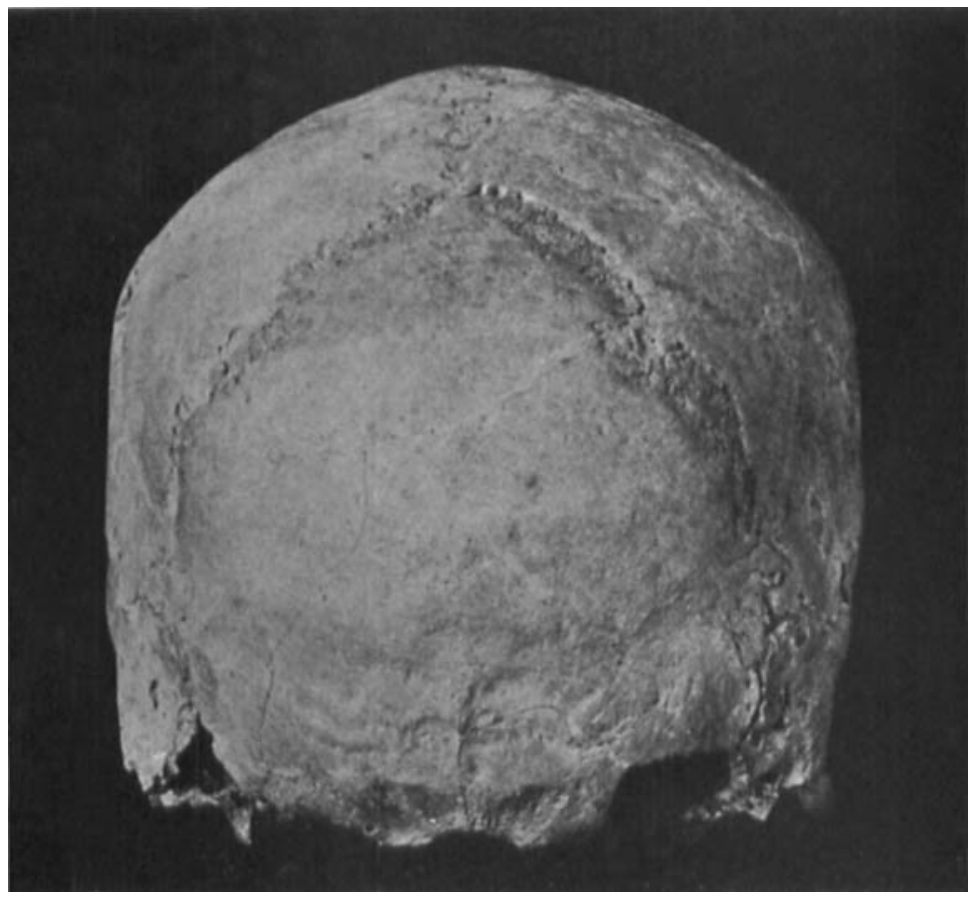

THE LANSING SKULL (FRONT AND BACK VIEWS.) 


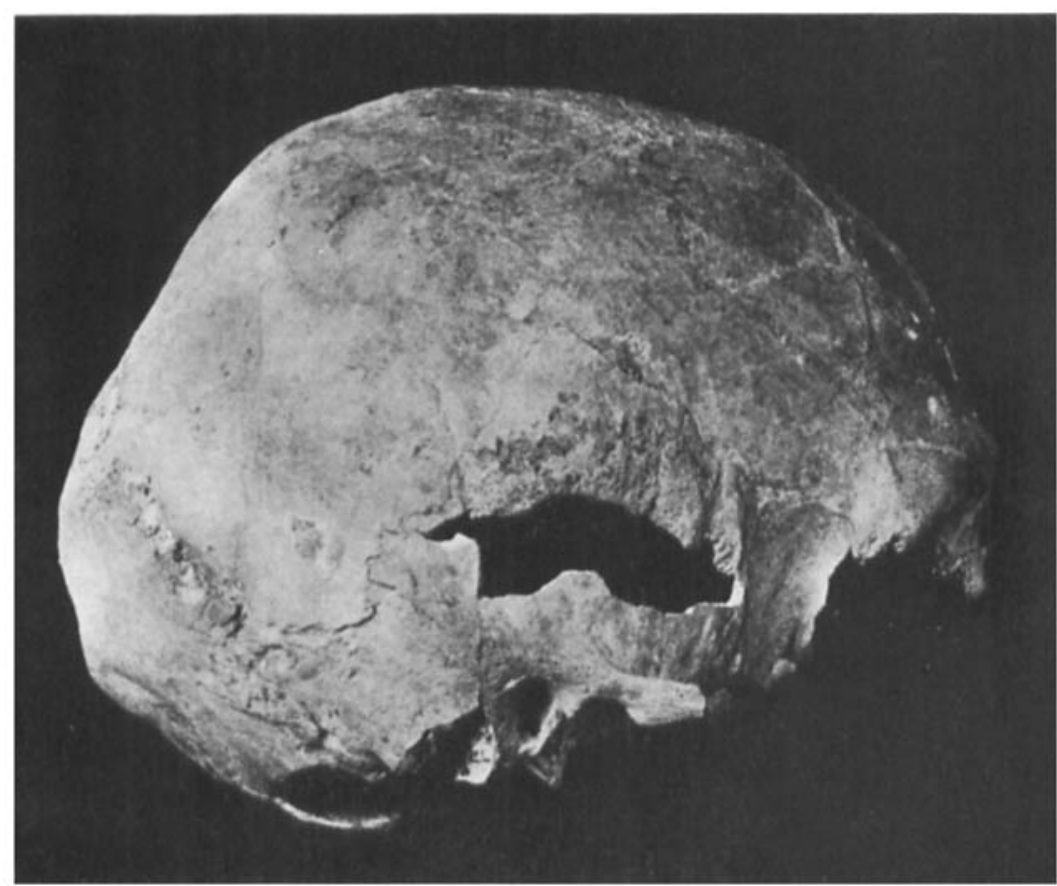

$c$

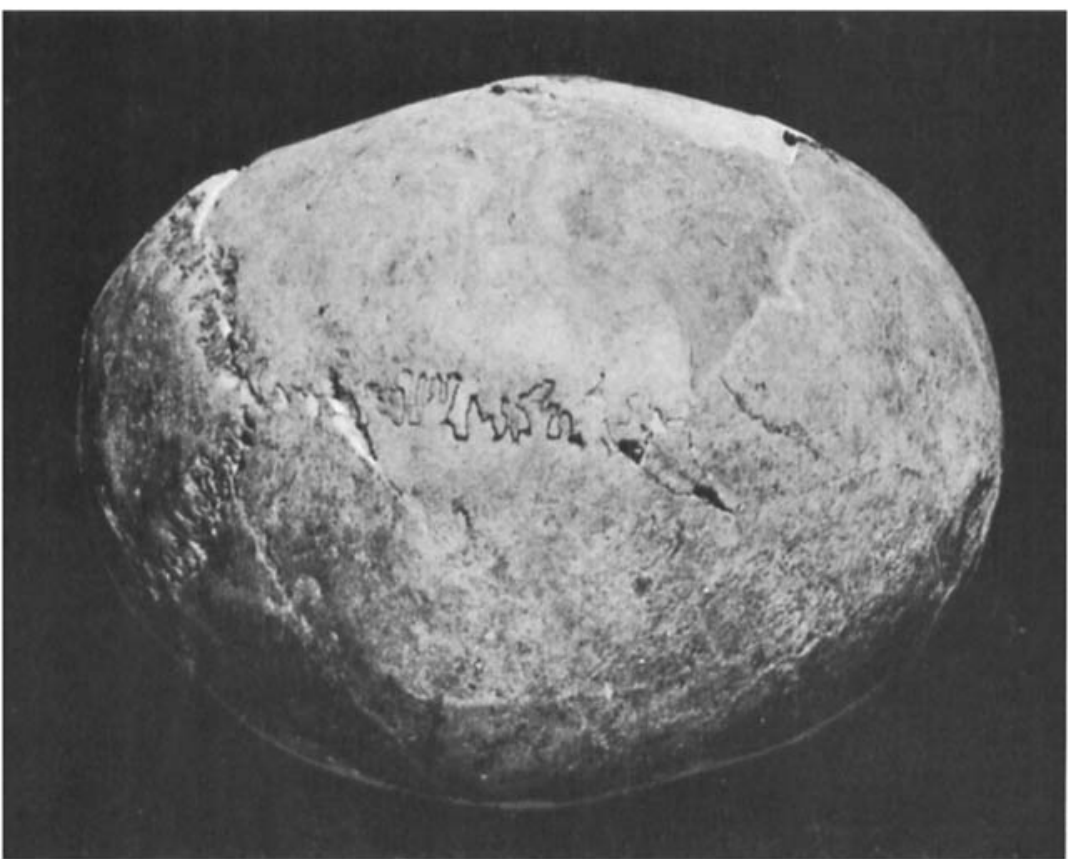

